\title{
11
}

\section{Territoriality in a Philippine Fishing Village: Implications for Coastal Resource Management}

\author{
Shio Segi, Department of Resource Management and Geography, Melbourne School of Land \\ and Environment, The University of Melbourne
}

\section{Introduction}

The study of local territorial arrangements has been an important approach to common property resource management including that of fisheries and coastal marine resources among scholars and practitioners over the last few decades (Pollnac and Johnson 2005:34). These scholars have been critical of the fact that modern 'top-down' style management based on economic models can be inappropriate in many parts of the world (Ostrom 1990). That common property resources in the sea be under an open-access regime is an assumption on which these centralised systems are often based and they can be both enormously costly as well as ineffective, and in the case of archipelagic nations the matter can be even more difficult (Ruddle 1996:334-335).

The management of resources in tropical waters is a daunting task as one needs to address the diverse variety of marine species captured by the diverse gear types of often diverse cultural groups in highly complex ecological systems (e.g., Johannes 1998). Further, as Ruddle and Hickey (2008) point out, an underlying and continuing colonialism and cultural imperialism, often embodied in donor-assisted resource management projects, intensify the challenge. Self-sustaining sitespecific resource management practices embedded in a local cultural and socio-economic context can thus have a significant role in the modern effective management of marine resources (Ruddle 2007:7).

Based on their rich local ecological knowledge, resource users have been practicing their preexisting local management systems in nearshore waters in many parts of Oceania, East Asia, Southeast Asia, and the South Asia region, and a customary marine tenure system is commonly in place in some areas (e.g., Peterson and Rigsby 1998; South et al. 1994). According to Johannes and Ruddle (1993:23), customary marine tenure is "a practice which involves the observation of exclusive fishing rights... [that] apply to specific areas, and may include rights to particular species, or to use of a particular gear type." 
In other parts of Southeast Asia at present, the concept of customary marine tenure is, however, neither common nor evenly distributed (Ruddle 1994:1-4). In the areas where a customary marine tenure system and traditional institutions continue to be present, such as in island-nations in Oceania, the recognition of the application of these management practices is being sought (e.g., Hviding 1998; Ruddle 1998a). In places where 'a strong traditional base' (Pomeroy 1995:145) for revitalising the pre-existing local management institution is absent, however, it seems that scholarly interest has been largely concentrated on establishing new regulatory regimes for community-based resource management. The Philippines provides a good example of this case. From archival records, Lopez (1985:196) noted that in the early Spanish colonial period in 17th century, some coastal Tagalog settlements in Luzon reserved some portion of the sea and river for their exclusive use. These areas were subjected to payment of a usage fee when used by non-constituents of the settlement. In some cases, according to him, these fishing grounds were bartered in the same manner as other commodities. Presumably, the concept of customary marine tenure with exclusive rights to usage once existed in at least some regions of Philippine communities, but, with a few exceptions (e.g., in Batanes Islands, see Mangahas 1994) these practices have long vanished over the more than 300 years of the colonial period (Ibid.:196). Under the open-access and centralised regime which was established during this period, resource depletion is taking place due to increasing fishing effort and technological advancement over the last century (e.g., Spoehr 1980).

Responding to decades of constant failure of such intrusive management strategies, the participation of local resource users in a decentralised manner became widely acknowledged as the key to more effective conservation of resources (Agrawal and Gibson 1999:631-633). In the case of the Philippines, the national government has shifted its approach to more localised control over resources since the 1990s.

In the course of the devolution, territorial restriction was used for controlling access to the resources under a co-management regime between the government and the resource users. Under the current legal framework (most importantly, the Fisheries Code of 1998 and the Local Government Code of 1991), municipal governments have major authority in the management of marine resources within their newly delineated jurisdictional waters. Meanwhile, local fishers are required to register to gain the right to exploit the resources. Upholding the tradition from the time of American occupation (Lopez 1985:196), the municipal governments have the authority to grant registered fishers the privilege of erecting fish corrals; oyster, mussel, and other aquatic beds; and milkfish fry areas in designated places within the municipal waters. At a more collaborative level, the creation of a marine protected area (MPA), managed by locally institutionalised organisations, has been one of the most common management tools in a growing number of coastal resource management projects (Pollnac et al. 2001:684). As a whole, recent resource management is characterised by the control of access to the resources by defining the eligible users and demarcating the accessible and non-accessible areas.

In many cases, but not all, the local marine resource management system is considered to be valuable in resource conservation as it involves autonomous control over access to the resources (McGoodwin and Dyer 1994:1). Even though there is on-going debate over how much local management contributes to actual resource conservation, locally appropriate management is "a vital aspect of the social and cultural constitutions of the complex resource system" (King 1997:424).

Despite the trend towards a strong focus on the creation and implementation of co-management of resources in the Philippines, there has been little attention to these non-traditional and informal practices for controlling the access to resources (Mangahas 1994:55). Regulating the access to resources through territorial control helps conservation, and a good understanding of the human 
dimension in this practice is essential (Christie 2004). The examination of locally practised territoriality should provide a valuable basis for the development of alternative approaches. Taking two case studies in a small fishing village in the Central Visayan region, this paper will focus on local claims of territoriality over fishing areas. It will examine how they are operated, rationalised, and related to the formal fisheries and coastal resource management framework.

The first case study represents the local territorial system practised by small-scale fishers to define the location of bottom-set gill nets in coastal waters. Fishers claim their exclusive right of use of certain netting spots where the operation is governed by a set of rules. The second case study deals with the small-scale fishers' territorial claim over distant waters where they compete fiercely with illegal commercial ring-netters. Unlike the first case, their claim is more discursive and unstructured, but there is a strong sense of territoriality based on the differentiation of social groups. While the first case involves a practical solution for avoiding risk and smoothing the fishing among local fishers, the second case involves the fishers' compelling case against exploitative outsiders and is motivated by perceived resource degradation.

This paper examines qualitative data that were collected through multiple semi-structured and unstructured interviews with small-scale fishers, non-fishing villagers, ring-netters, and government officers in the course of 14 months fieldwork (February 2006 to April 2007). Data were also collected through participatory observation of village life and a total of 15 fishing trips with ring-netter crews.

\section{Case Studies}

\section{Research setting}

The municipality of Boljoon is located on the southeast coast of Cebu Island facing Bohol (Cebu) Strait, approximately $100 \mathrm{~km}$ south of Cebu City (Figure 1). Small in population and a considerable distance from commercial centres in the region (such as Cebu City and Dumaguete City), the town has no substantial commercial industry other than small-scale and primarily subsistence farming and small-scale fishing. Nevertheless, fishing is economically and nutritionally important, and compared to neighbouring towns, a larger percentage of the of the population of Boljoon engages in fishing (CRMP 2004).

Barangay $^{I}$ Granada is a well known fishing centre in the municipality. Among 180 households along the coast, 68 regularly engage in fishing, and for most, it is their main source of household income. From these households, at least 101 small-scale fishers use more than 20 types of fishing methods, which differ according to target species and fish habitat. Situated in an area of two relatively healthy coral reefs, some fishers use gill nets to target reef species in the coastal waters adjacent to the village. A larger number of fishers use hook-and-line methods, mainly targeting small pelagic species in off-shore waters close to Bohol Island, across the strait.

\section{Case study I: Allocation of netting spots}

In the approximately 400-metre stretch of coastal waters and directly facing the most densely populated part of the village of Granada, small-scale fishers using bottom-set gill nets have established a territorial (teritoryo) system ${ }^{2}$ and operational rules. The area has a coral reef at each end. The area of sandy substrate between the reefs is the preferred fishing zone for net fishing

\footnotetext{
1 The Barangay is the smallest administrative unit in the Philippine system and it is similar to the notion of a village.

2 Though the exact origin of this is unknown, the fishers thought it had developed after the late 1980s, when the number of bottom-set gill nets in the coastal water gradually increased. Similar development of territorial systems for beach seining was observed in southern Palawan (Veloro 1992).
} 
because of its high productivity, low risk of gear damage and easy access to the fishers' residences. Three types of bottom-set gill nets used in this area are locally called pamo, pangmalangsi, and pangsolid for overnight set (pana-an), mainly targeting reef-associated species such as fusilier (Caesio sp.), herring (Spratelloides sp.), and emperor (Gnathodentex sp., Lethrinus sp.). In general, local fishers from both Granada and adjacent barangays use this area for various methods, but it is only Granada fishers who use the above-mentioned nets.

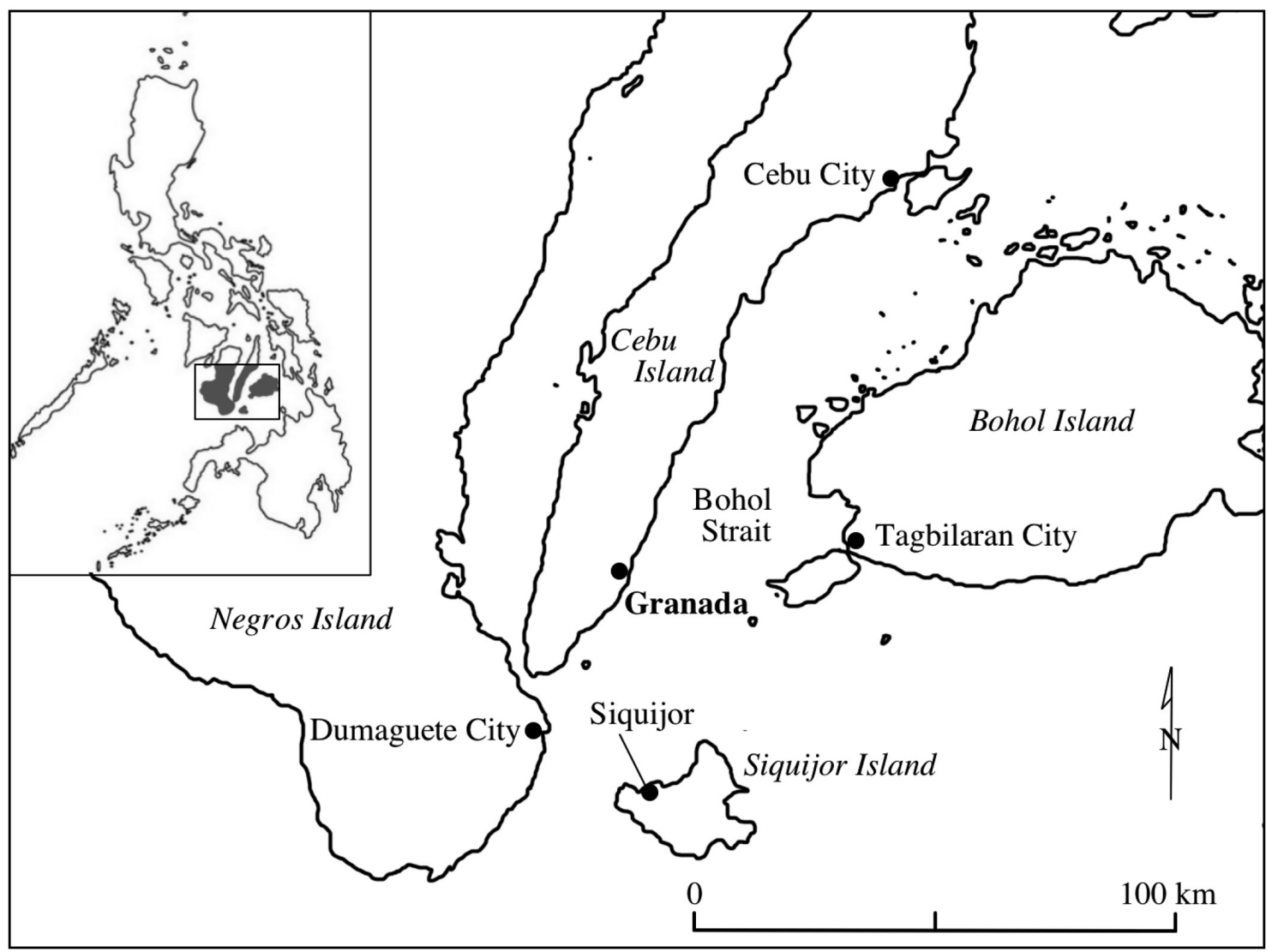

Figure 1. Map of the research area in Central Visayas.

Source: Map by Shio Segi.

These coastal waters are divided into 25 territories as a 'netting location' (taktak-an) shared by 18 Granada fishers, some of whom have multiple territories (Figure 2). In each territory, a rightholder has an exclusive right to place the net at roughly right angles to the shoreline. He sets it in late-afternoon and hauls it in early on the following morning. An individual's territory is usually located near his house or the land he owns and is the same as the beaching location of his boats. Although some spots are more scattered, owing to their perceived lower productivity, others, perceived as either more productive or easily accessible, are clustered tightly at intervals of about 5 metres. Nets are not set in coral reefs or their immediate vicinity, since they would be easily entangled in the coral, thereby incurring damage which would be expensive to repair. 


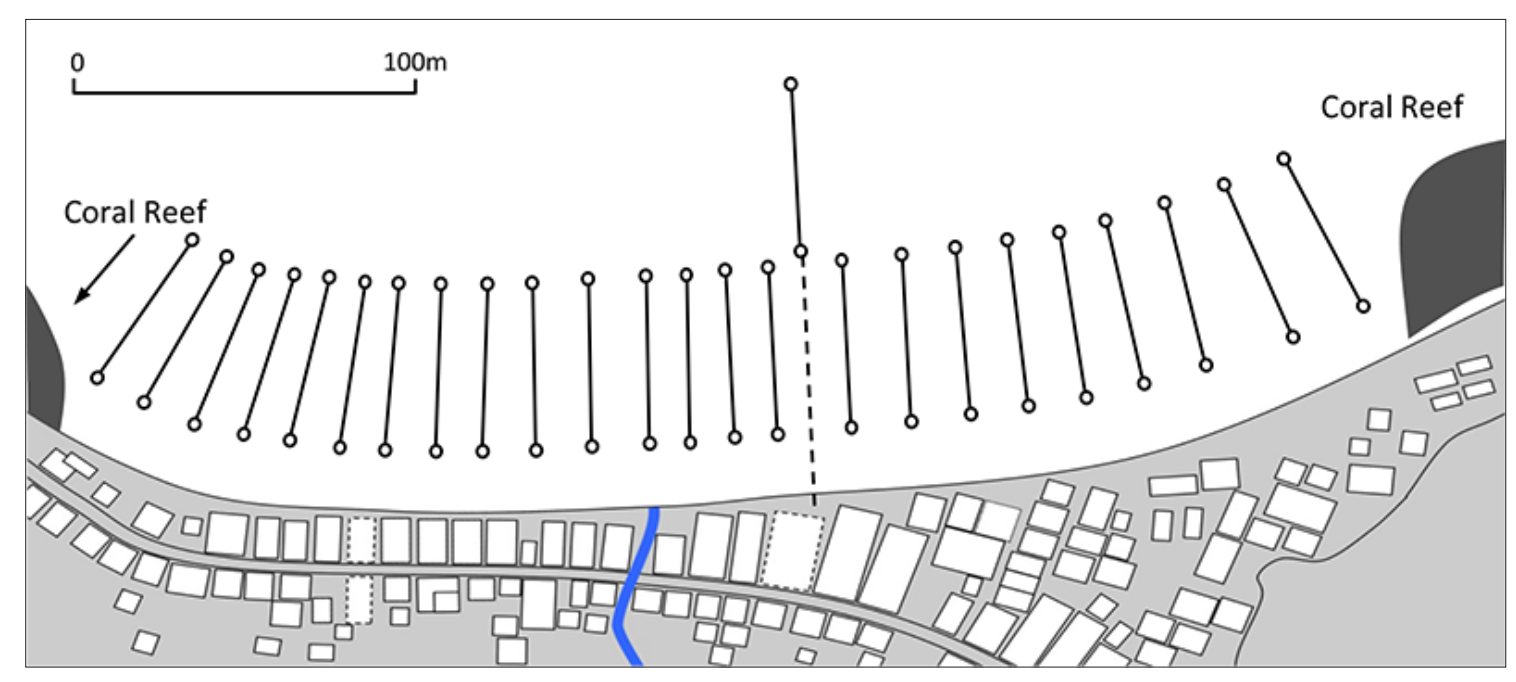

Figure 2. Territory for bottom-set gill net fishing in Granada.

Source: Shio Segi.

The rationale underlying these territorial claims is the fishers' long-standing and continuous use of the netting spots which are located close to their residences. Commonly, there is an implicit understanding among resource users that continuous use of the area for an extended period would generate a preceding use-right over others. Such a territorial claim based on the perception of long-standing use is not unusual in the Asia-Pacific region, including the Philippines (e.g., Cruz 1986; Veloro 1992), and often such claims are supported by formal as well as informal sets of rights and rules (Ruddle 1998b). In Quang Binh Province of Vietnam, for example, fishers hold several types of right which are structured according to a set of rules which define both socioeconomic and operational aspects of fishing operation (Ibid.). Similar to this case, and in other parts of the Philippines (e.g., Russell and Alexander 2000:23), Granada fishers reinforce their territorial claim with a strong sense of 'household proximity right' which conceptually allows one to claim a prior use-right over the space close to one's residence or land. On the congested beachfront, this concept is used together with the first-comer rule when household proximity is a source of contestation for the preferential right holder.

This territoriality fulfils two main functions. The first is to secure an individual's netting location free from competition. Not only can the competition over the fishing spot easily lead to a souring of relations with others, but it is also an important concern for fishers to limit their fishing in order to keep it efficient (McCay 1978). When the fishing area is tightly limited and alternative fishing areas are not located within easy access, fishers face a situation in which they need to regulate others in their placing of nets. The fishing territory system thus both minimises the competition as well as setting the basis for operational arrangements in actual use.

As important as securing the fishing spot, the second purpose is to keep a certain distance between each net in order to avoid damage. Closely placed nets are vulnerable to entanglement (gubot) with other nets, particularly when current movements are less predictable. Also, when the nets are placed too close to each other, the catch may not be as good as it is when nets are better placed. In order to make sure each net is placed in the right way - that is, in the right fishing spot and at an appropriate distance from one another - fishers have made an operational rule to specify the time to place the nets collectively. Fishers who plan to put the net in that afternoon need to come out to the shore roughly before $5 \mathrm{p} . \mathrm{m}$. so that they can place the net in collaboration with the other fishers. To put into operation each claimed territory, concurrent placement functions to reduce the risk of entanglement arising from uncertainty at each fishing trip. The placement 
of a net in relation to other fishers' nets needs to be adjusted to the movement of the current of the day, but most importantly, fishers find it important to place them together so that they know where others' nets are actually placed in relation to their own net.

The crucial difference to the above example from Vietnam, however, is the lack of a well-organised institution. While property rights and operational rules are rather clearly arranged, there is no clear decision-making structure, as no committee or organisation has ever been established. The Barangay council (the village legislative body) has no involvement in it either, as this informal arrangement is outside of the concern of formal political institutions. Nor does anyone seem to hold any special authority to administer the arrangement. Individual right-holders are equal constituents within the arrangement. Thus, detailed administrative rules over the rights and operations are certainly very vague. Because the territory has no legal legitimacy, no exclusive right-holder can claim against another fisher for infringement of his financial value. The territory can be lent, however, providing verbal permission has been obtained from the right-holder prior to fishing. Though no fee payment or other obligation is established for this, fishers who borrow a territory are morally expected to share the catch with the right-holder when it is sizable. While some fishers claim that territory also can be transferable to a successor, provided he owns a net, it seems there is no consensus among right-holders. Given that current right-holders are the first generation of this arrangement, the handing on of the rights has not yet been an issue.

Lack of organised institutions, however, does not mean that there is no form of an institution. Monitoring for whether fishers are following the arrangement is conducted mutually throughout fishers' day-to-day lives and particularly at the daily gathering in the late-afternoon before fishing. As for sanctioning the offenders, social criticism and compensation for the damage is likely if the wrongly placed net gets entangled with others. Though there was no case of breaching the rules by other fishers during the author's stay, one ring-net vessel, unaware of the net, damaged the net with its anchor and faced two full days of repairing the net for compensation. Social criticism resulting from deviating from the locally shared norms in general cultivates the grounds for further physical and verbal harassment (Russell and Alexander 2000:26). Although there is no organised institution governing the arrangement, right-holders are motivated to mutually respect each other's territory and rights. When the area is only used by fishers from the immediate village and pressure of new entrants to the territory is limited, loosely organised arrangements have been able to effectively and autonomously control access to the resources for at least a couple of decades.

\section{Case study II: Fishing ground for small-scale fishers}

Among lowland Filipinos, fishers generate their sense of territoriality in relation not only to the practicalities of fishing, but also to the security of minimal living standards based on status group. Russell and Alexander (2000) argue that small-scale fishers in Batangas Bay established the sense of territoriality for local fishers against foreign baby purse-seiners. ${ }^{3}$ They argue that the local fishers institutionalised various forms of catch-sharing practice from the purse-seiners as a de facto 'tax' to access the resources in their territorial waters. As they point out, among local fishers this "relatively new strategy to keep other boats out of one's home bay" (Ibid.:23) is not unusual in the Philippines and a similar claim was made by small-scale fishers in Granada.

This type of claim is largely grounded in unequal power relations between the small-scale fishers and commercial fishers. Undoubtedly, it goes well beyond the realm of resource use at the village level. A fuller account of the underlying relationship requires a much wider understanding of the

3 Baby purse-seiners (locally called pukotan) are large double-outrigger motorised canoes crewed with 10-20 members. According to Philippine law, they are categorised as commercial fishing. 
socio-political context. Also, as the case of Batangas Bay showed, such a catch-sharing practice constitutes an important way of smoothing out the relationship between local and foreign fishers at the site of this case study. Though these points are obviously important, full discussion of these issues is beyond the scope of this paper (for a full account on these issues, see Segi, forthcoming).

In Bohol Strait, the relatively calm sea and migratory movement of small pelagic species attracted a number of commercial ring-netters $(k o b k o b)$ who visited the area annually from other parts of Central Visayas. Their major target species are bullet tuna (Auxis rochei rochei) from March until July and mackerel scad (Decapterus macarellus) from August until October. Fishing usually takes place around the southwest coast of the Province of Bohol and the adjacent Panglao and Balikasag islands. In this area, there is said to be a large number of Fish Aggregative Devices (FADs) called payao, installed mostly by the operators and associates of ring-net fishing in Bohol. Having their subordinating light boats illuminate the sea surface to aggregate the fish at the payao, ring-netters catch a large quantity of fish in one swoop. Employment of modern technology such as fish finders and sonar has contributed to the increase in excessively efficient operation. Fishing can be done up to three times a night and an overnight catch sometimes reaches over 4 metric tons. Though there are no data indicating the number of ring-netters operating in the area, the array of illumination at payao, almost forming a continuous line of light which can be seen from a distance, indicates the intense fishing effort in the area. Owing to their highly efficient fishing methods and the large number of boats in operation, everyone interviewed, both among resource users as well as those involved in resource management, agreed there had been significant resource depletion from over-exploitation.

Excessive use of the resources has affected the lives of small-scale fishers in Granada through resource competition over already depleted resources. These fishers employ a multiple hook-andline (palangre) method to target the same species at the payao in the same area as ring-netters operate. In the perception of small-scale fishers, their catches drop significantly while ring-netters are in their prime season and it significantly affects their livelihood. Not only are they affected by the decreased catch, but they also suffer from a worsening fishing economy from price drops due to the consequent over-supply of fish to the local market by ring-netters. This situation has heightened their concern about the future prospects of the resources, as Granada fishers often commented that: 'fish will be exhausted (mahurot na isda)' because 'they will catch everything (makuha nila tanan)'. Because of the dual effect on quantity and price of the catch, Granada fishers have become extremely pessimistic regarding the future status of the resources and their vulnerable livelihood.

As a response, Granada fishers have been vocal about pushing out the ring-netters from the area by claiming that the area is for small-scale fishing. The rationale of their claim is at least partly based on the concept of delineated Municipal Waters. Under the Philippine Fisheries Code of 1998, the waters up to 15 kilometres off-shore are marked as 'municipal water' which the local government reserves for small-scale fishers, and usually no commercial fishing is allowed. Given that the narrow strait is less than 30 kilometres at its widest, all the ring-netters in this area are considered illegal fishers and only small-scale fishing is allowed.

Despite the fact that the law grants no more than the use right, small-scale fishers in Granada call the disputed fishing area 'our sea' (dagat namo) and claim the area is the territory for small-scale fishers. Continuous encroachment of ring-netters into the area is often described as 'stealing' the fish that small-scale fishers were supposed to catch. To support the territorial claim, Granada fishers often postulate two reasons. Firstly, Granada fishers explain that this area should be used only by locals (taga diri). With limited mobility in their fishing style, fishers claim that the resources are not abundant enough to share with non-locals who have access to their own waters. 
This exclusivity based on the 'local-foreign' distinction is not only directed at the commercial fishers, but also at small-scale fishers who periodically visit the area from other places. Secondly, ring-netters are usually operated by capitalists and they have no trouble living a comfortable life and finding the means to make a living. By contrast, small-scale fishers live in poverty and are often unable to meet daily expenses and they are only able to gain a small livelihood. The gap in the reality of social class causes small-scale fishers to feel that ring-netters pose an unjustifiable threat to their humble livelihood. Thus, their claim to the territory of small-scale fishing is really a claim by the poor aimed at protecting their 'right to survive' against the rich who threaten the territory which provides their sole and irreplaceable livelihood.

\section{Discussion}

From two case studies, different types of territorial claims in both coastal and off-shore waters have been demonstrated to exist simultaneously in one small village. In this, it became clear that there are several rationales raised by fishers to justify their claim to the territory. As observed in many places, use of a location for an extended period of time is a powerful basis for the claim in the Philippine context. Obviously, the range of duration at the basis of their claim differs in each case. In regard to netting space, some referred to a period of two generations while others referred to about 10 years of use in their narratives. The important attribute is that they had been using the area with the stationary gear before anybody else and uncontested over the years. This generates some kind of a sense of 'title-by-occupancy' which gives moral support to their ongoing exclusive use of the location.

Also, the sense of 'localness' is becoming an important trait as resource degradation continues. In Philippine fishing communities, a distinction in the social groups between 'local' and 'foreign' has been seen to influence their relationship to the resources (Russell and Alexander 2000; Zayas 1994). Again, there is no consistent definition of perceived 'localness' among fishers, as it may refer to the village-level or even the wider area over several municipalities, regardless of the jurisdictional borders. An important aspect, however, is that these fishers are heavily reliant on the area as the location of the daily earning of their livelihood and no alternative locations are easily accessible.

Finally, territorial claims are also made on the basis of the differentiation between social status groups. With less and limited means of production and vulnerability in their livelihood, poor fishers claim their local area must be used in order for them to survive, given their harsh living conditions.

As the central purpose of fisheries management is to place control over fishing, both cases suggest that the territorial claims are at least partially successful in restraining the fishing pressure. In the netting territory system, fishers acknowledge that the area is already fully occupied and there is no safe and productive spot for a new net to join in. As a result, this regulates the number of nets for overnight use because of the prospect of lower productivity and the higher risk of nets being damaged. Also, in the case of the territorial claims of small-scale fishers in off-shore waters, their claims led to stricter law enforcement. With active support of a conservation NGO, small-scale fishers along southeast Cebu managed to push local governments to introduce more systematic patrolling and fee collection activities, which discouraged ring-netters to intrude into municipal waters. Though there are no quantitative data to estimate the actual conservation effect, these examples show that the fishers' territorial claims have at least contributed to controlling access, which may slow down the depletion process of the resources.

Both cases show that fishers' territorial claims emerged out of necessity; however, this was not an inevitable result (Dyer and McGoodwin 1994:1). In coastal waters, increased risk of damaging 
expensive gear motivated fishers to creatively establish a self-restraining netting arrangement on their own initiative. Meanwhile, in off-shore waters, the impending threat of a degraded household fishing economy as a result of resource depletion and price fall triggered by ringnetters were the motives behind competing fishers' strong claim of territoriality. Although in both cases these fishers are aware that there is no legal basis for their claims, they choose to take active control over the fishing ground in order to protect their livelihood. While these issues are undoubtedly common to small-scale fishers in many societies, it is not the case that all fishers faced with this resource problem would make similar territorial arrangements. These territorial claims largely involve the cultural and socio-political dimensions of the locality in defining who they are and on what grounds they would have prior rights over others. These territorial claims are an active and practical response, based upon locally constructed legitimacy, to the risks and uncertainties in fishing and resource conditions.

In both cases, the articulation of the claim is aimed at keeping the fishers' livelihood economically viable as well as at the conservation of the resources, but only for their own use, not for solely environmental purposes. Similarities were also seen in a Tagalog fishing community (Russell and Alexander 2000:36) and elsewhere (e.g., Pollnac and Johnson 2005). Specifying the netting location does not only reduce the risk of entanglement, but also increases one's chance to catch more fish because of wider net-intervals and a smaller number of units. Similarly, reducing the number of exploitative commercial fishing vessels would likely return a greater catch to small-scale fishers. Thus, it is obvious that the impact on fishers' livelihood is the important determinant of the fishers' interaction with the resources and attempt to control them. This echoes and reinforces the argument that a perceived positive economic benefit on the part of small-scale fishers is the most significant indicator of success in coastal resource management projects, rather than resource conservation on its own.

\section{Conclusion}

Although its effect may be limited, the value of attempted local management can be considerable. King (1997:424) contends that the value of local management lies in "their social structural characteristics within which and by which resource appropriators... are able to, allowed to, or are willing to have a voice or play some role in determining the allocation and distribution of the [common property resources]." In this regard, these examples of local territoriality claims shed light on the ability and motivation of Philippine small-scale fishers to take an active and responsible role in controlling the resources for an even more autonomous, equitable, and socially inclusive management regime.

Because the sustainability of 'community-based' coastal resource management after the termination of a project is commonly an issue in the Philippines, meaningful participation of resource users who would like to generate the sense of 'ownership' in the project is a crucial issue (Pollnac and Pomeroy 2005:248-249). With the utilisation of territorial control in mind, these fishers' claims, which are deeply grounded in the cultural and socio-economic condition of the locality, may have important implications for the crafting of more effective coastal resource management strategies (Russell and Alexander 2000:37). Unfortunately, formally institutionalising this territoriality as marine tenure may not be a realistic option in the Philippines due to the unstable social structure and the lack of social institutions (Martin-Smith et al. 2004:184). Legal acknowledgement of the territorial claims and arrangements, however, coupled with supplementary formal resource management measures, may provide an increased moral investment on the part of locals in managing the resources, and this may help sustain such projects. Needless to say, substantial 
involvement of resource users in this formalisation process is essential (Palmer 1994:246). Resource managers should not overlook the often inconspicuous self-governing arrangements and territorial claims of resource users.

The above does not suggest, however, that territorial arrangement on its own is the solution for achieving more effective resource management. Indeed, as is evident in the case of fishers' claims over off-shore waters, one needs to note that the emergence of these territorial arrangements can be closely associated with the power struggle of resource users who are under threat of marginalisation and exploitation (Segi forthcoming). When unequal power relations penetrate the society and thus impinge on the use and management of resources, one needs to establish such territorial arrangements within the wider power relationships among stakeholders, not only at the local level but also within the vertical political structure from village to national level. Indepth research into local territoriality with multifaceted approaches to the social and political environment is thus necessary for designing meaningful and realistic forms of more socially sound management.

\section{Acknowledgements}

The research for this paper was undertaken with the support of The Australian National University. I am particularly grateful to Kenneth Ruddle, Nicolas Peterson, and anonymous reviewers for their insightful and constructive comments in the development of the manuscript. Also I would like to thank Madeleine Strong-Cincotta for assistance with editing. My sincere gratitude also goes to the people in Boljoon, especially small-scale fishers in Granada, ring-net crew members from Negros Oriental and Bohol, and the Coastal Conservation and Education Foundation, Inc. for their kind cooperation and engagement.

\section{References}

Agrawal, A. and C.C. Gibson. 1999. Enchantment and disenchantment: The role of community in natural resource conservation. World Development 27(4):629-649.

Christie, P. 2004. Marine Protected Areas as Biological Successes and Social Failures in Southeast Asia. American Fisheries Society Symposium 42:155-164.

Coastal Resource Management Project. 2004. Unpublished electronic database: Estimated number of municipal fishers and boats in the Municipality of Sibonga, Argao, Dalaguete, Alcoy, Boljoon, Oslob, and Santander.

Cruz, W.D. 1986. Overfishing and conflict in a traditional fishery: San Miguel Bay, Philippines, Proceedings of the Conference on Common Property Resource Management, pp.115-133. Washington D.C.: National Academy Press.

Dyer, C.L. and J.R. McGoodwin. 1994. Introduction. In C.L. Dyer and J.R. McGoodwin (eds), Folk management in the world's fisheries: lessons for modern fisheries management, pp. 1-15. Niwot: University Press of Colorado.

Hviding, E. 1998. Contextual flexibility: present status and future of customary marine tenure in Solomon Islands. Ocean and Coastal Management 40:253-269.

Johannes, R.E. 1998. The case for data-less marine resource management: examples from tropical nearshore finfisheries. Trends in Ecology and Evolution 13(6):243-246.

Johannes, R.E. and K. Ruddle. 1993. Human interactions in tropical coastal and marine areas: lessons from traditional resource use. In A. Price and S. Humphrey (eds), Applications of the biosphere reserve concept to coastal marine areas, pp. 21-27. Gland: International Union for the Conservation of Nature. 
King, T.D. 1997. Folk management among Belizean lobster fishermen: Success and resilience or decline and depletion? Human Organization 56(4):418-426.

Lopez, M.G. 1985. Notes on Traditional Fisheries in the Philippines. In K. Ruddle, R.E. Johannes and UNESCO Regional Office for Science and Technology for Southeast Asia (eds), The Traditional knowledge and management of coastal systems in Asia and the Pacific: papers presented at a UNESCOROSTSEA regional seminar held at the UNESCO Regional Office for Science and Technology for Southeast Asia, 5-9 December, 1983, pp. 193-206. Jakarta: United Nations Educational Scientific and Cultural Organization Regional Office for Science and Technology for Southeast Asia.

Mangahas, M.F. 1994. Traditional marine tenure and management in ASEAN. In R.G. South, D. Goulet, S. Tuquri, and M. Church. (eds), Traditional marine tenure and sustainable management of marine resources in Asia and the Pacific, pp.48-58. Suva: International Ocean Institute-South Pacific.

Mangahas, M.F. 1994. Indigenous coastal resource management: the case of Mataw fishing in Batanes. U.P. Assessment Project on the State of the Nation; no.94/001, Quezon City: University of the Philippines Center for Integrative and Development Studies.

Martin-Smith, K.M., M.A. Samoilys, J.J. Meeuwig, and A.C.J. Vincent. 2004. Collaborative development of management options for an artisanal fishery for seahorses in the central Philippines. Ocean and Coastal Management 47:165-193.

McCay, B.J. 1978. Systems ecology, people ecology, and the anthropology of fishing communities. Human Ecology 6(4):397-422.

McGoodwin, J.R. and C.L. Dyer. 1994. Folk management in the world's fisheries: lessons for modern fisheries management. Niwot: University Press of Colorado.

Ostrom, E. 1990. Governing the commonn: the evolution of institutions for collective action. Cambridge: Cambridge University Press.

Palmer, C.T. 1994. Are folk management practices models for formal regulations? Evidence from the lobster fisheries of Newfoundland and Maine. In C.L. Dyer and J.R. McGoodwin (eds), Folk management in the world's fisheries: lessons for modern fisheries management, pp. 237-249. Niwot: University Press of Colorado.

Peterson, N. and B. Rigsby (eds). 1998. Customary Marine Tenure in Australia. Sydney: Oceania Publication, University of Sydney.

Pollnac, R.B., B.R. Crawford, and M.L.G. Gorospe. 2001. Discovering factors that influence the success of community-based marine protected areas in the Visayas, Philippines. Ocean and Coastal Management 44(11-12):683-710.

Pollnac, R.B., and J. Johnson. 2005. Folk management and conservation of marine resources: Towards a theoretical and methodological assessment. In N. Kishigami, J.M. Savelle and K.M. Hakubutsukan (eds), Senri ethnological studies, no. 67: 33-50 Indigenous use and management of marine resources, p. 455. Osaka: National Museum of Ethnology.

Pollnac, R.B. and R.S. Pomeroy. 2005. Factors influencing the sustainability of integrated coastal management projects in the Philippines and Indonesia. Ocean and Coastal Management 48(3-6):233-251.

Pomeroy, R.S. 1995. Community-based and co-management institutions for sustainable coastal fisheries management in Southeast Asia. Ocean and Coastal Management 27(3):143-162.

Ruddle, K. 1994. A guide to the literature on traditional community-based fishery management in the AsiaPacific tropics. Rome: Food and Agriculture Organization of the United Nations.

Ruddle, K. 1996. Traditional management of reef fishing. In N.V.C. Polunin and C.M. Roberts (eds), Reef fisheries, pp. 315-335. London: Chapman and Hall. 
Ruddle, K. 1998a. The context of policy design for existing community-based fisheries management systems in the Pacific Islands. Ocean and Coastal Management 40(2-3):105-126.

Ruddle, K. 1998b. Traditional community-based coastal marine fisheries management in Viet Nam. Ocean and Coastal Management 40(1):1-22.

Ruddle, K. 2007. Fishing rights: misconceptions, outright prejudice. Samudra The Triannual Journal of the International Collective in Support of Fishworkers Report No. 48:4-9.

Ruddle, K. and F.R. Hickey. 2008. Accounting for the mismanagement of tropical nearshore fisheries. Environment, Development and Sustainability 10:565-589.

Russell, D.S., and T.R. Alexander. 2000. Of Beggars and Thieves: Customary Sharing of the Catch and Informal Sanctions in a Philippine Fishery. In E.P. Durrenberger and T.D. King (eds), State and community in fisheries management: power, policy, and practice, pp. 19-40. Westport: Bergin and Garvey.

Segi, S. forthcoming. Losing at sea, winning on land: a case study of Philippine small-scale and industrial fisher resource competition. Society \& Natural Resources.

Segi, S. 2011. 'Pinning Our Hope on the Seas': Conservation, Resource Depletion and Livelihood in a Philippine Fishing Village. PhD Thesis, Canberra: The Australian National University.

South, R. G., Goulet, D., Tuquri, S., and Church, M. (eds). 1994. Traditional marine tenure and sustainable management of marine resources in Asia and the Pacific, Suva: International Ocean Institute-South Pacific.

Spoehr, A. 1980. Protein from the sea: technological change in Philippine capture fisheries. Pittsburgh: Department of Anthropology, University of Pittsburgh.

Veloro, C. 1992. Complementary adaptations, contrasting images. Yakara 19:76-110.

Zayas, C.N. 1994. Pangayaw and Tumandok in the Maritime World of the Visayan Islanders. In I. Ushijima and C.N. Zayas (eds), Fishers of the Visayas, pp. 75-131. Quezon City: CSSP Publications in co-operation with University of the Philippines Press. 